\title{
Flood risk management on Sakhalin Island
}

\author{
Yurij Gensiorovskiy ${ }^{1, *}$, Nikolaj Kazakov ${ }^{2}$, Darya Bobrova $^{2}$, Ekaterina Kazakova ${ }^{2}$, \\ Aleksandra Muzychenko ${ }^{1}$, Svetlana Rybalchenko ${ }^{2}$, Semen Zhiruev $^{3}$, Leonid Muzychenko ${ }^{1}$ \\ and Sergei Kudriavtcev ${ }^{4}$ \\ ${ }^{1}$ Far East Geological Institute Sakhalin Department FEB RAS, Yuzhno-Sakhalinsk, Russia \\ ${ }^{2}$ Special Design Bureau for Marine Research Automation Tools of the Far Eastern Branch of the \\ Russian Academy of Sciences , Yuzhno-Sakhalinsk, 694023, Russia \\ ${ }^{3}$ Autonomous Non-Commercial Organization Scientific Research Centre "Geodynamiks", Yuzhno- \\ Sakhalinsk, Russia \\ ${ }^{4}$ Far Eastern State Transport University, Khabarovsk, Russia
}

\begin{abstract}
The paper considers the flooding factors of urbanized territories on the Sakhalin island in the typhoons and deep cyclones evens. According to observations of the hydrological regime, floods caused by melting snow usually capture only a small part of the territory of the urban district. In the summer-autumn period, the formation of floods is associated with a large amount of precipitation during the passage of deep cyclones and typhoons over the Sakhalin island territory. Measures are proposed to reduce flooding risks at the town planning documentation development stage.
\end{abstract}

\section{Introduction}

The Sakhalin Region is one of the most dangerous regions of Russia from the floods threat point of view and the associated channel processes activation for the population and the economy. There are over 60 thousand rivers and streams on the Sakhalin island territory [Atlas of the Sakhalin Region]. Despite the small settlements areas, there are from 2 to 14 rivers or streams within their borders. Most of the Sakhalin island rivers are classified as torrent and semi-torrent. Most of the Sakhalin rivers basins lie in the absolute heights range $350-1200 \mathrm{~m}$ with a relief subdivision depth $250-1000 \mathrm{~m}$. The river basin areas are often 1-15 $\mathrm{km} 2$, the watercourses length is 3-10 km; weighted average channel inclination - 40-60 \% ; the maximum slope is more than $100 \%$, the small rivers catchments slopes can reach 500 $\%$.

The Sakhalin island characteristic rivers basin areas are in range from 15 to $600 \mathrm{~km} 2$, the average basin areas slopes are 300-500 \%, which provides a rapid moisture runoff during snowmelt and, especially, in heavy rainfall during the summer-autumn period. In the mean water the riverbeds width does not exceed 3-10 m, the flow velocities at the ripples are 0.3$0.5 \mathrm{~m} / \mathrm{s}$, the depth varies from 0.1 to $0.7 \mathrm{~m}$. Often, the runoff ceases within the city limits. During the rain floods passage, the channels width increases to $50-100 \mathrm{~m}$, and the current speed - up to 3-4 m/s, the high waters level can rise above 4-6 m. As a result, the water flow

\footnotetext{
*Corresponding author: gensiorovskiy@mail.ru
} 
eroding capacity sharply increases. Large catchment areas are deforested as a result of forest fires and intensive felling. All this causes the lateral and deep erosion processes development on the Sakhalin rivers. High floods are observed on average once every 3-4 years. The average floods duration on rivers with areas less than $1000 \mathrm{~km} 2$ is 6-15 days, on larger ones - 15-18 days [1-4].

\section{The problem formulation}

During the typhoons and cyclones passage, which bring abundant precipitation, the river swater levels rise occurs in a few hours. As a rule, during the floods passage, settlements territories are flooded. The flooding areas can be tens of square kilometers, and the width of intensive channel erosion zone is up to $2 \mathrm{~km}$ [4].

For the period from 1947 to 2018 years on Sakhalin island, the following floods can be considered the most serious with the flooding of a large area of settlements: 1947, 1955, $1970,1972,1978,1981,2002,2009,2012,2015$. Thus, the frequency of floods is 1 time in 7 years, which corresponds to the humidification cycles of the Sakhalin island territory. In the XX century, the most severe flood was observed on August 5 - 7, 1981, during the typhoons "Ojin" and "Phyllis". Flooding was preceded by a long period of humidification, determined by climatic factors: snowy winters, cold lingering spring, wet summers. Immediately before the release of typhoons (August 3,1981) a cyclone passed through the south of Sakhalin, accompanied by intense rains, thereby increasing the overall moistening of the territory. The intensity of precipitation was 30 to $100 \mathrm{~mm}$ for 12 hours, 150 to $400 \mathrm{~mm}$ of precipitation fell, which amounted to a one and a half to three month rate for August 1981. After of significant precipitation on August 5 and 6, the levels on the rivers of Southern Sakhalin increased for 3-6 m, in relation to the levels preceding the rise (August 1, 1981). In some parts of the rivers - in the narrow valleys - the rise in the water level reached 6-10 m. The width of the flooding floodplain of large rivers reached $10-15 \mathrm{~km}$. As a result of the release of water to the floodplain of the rivers and streams of the south of Sakhalin, 12 cities, 17 villages and more than 40 other settlements were completely or partially flooded

The causes of floods due to anthropogenic impact can be reduced to several groups. The woody vegetation lack on large catchments areas as a result of its reduction. The waterproof coatings (asphalt, concrete, etc.) increase in the areas leads to an increase in the maximum flow in the city. Existing urban storm drainage systems do not cope the volumes of incoming thawed and rainwater, which leads to territory flooding. Storm sewers often do not cover the wholeurban development area. Water live cross section stamping as a result of the bridge crossings construction leads to channel culvert function violation and, as a consequence, to shore erosion and flooding [2]. Snow warehousing during clearing from urban areas to snow dumps leads to large snow fields formation within the city limits, which water equivalent can exceed $500000 \mathrm{~m} 3$ of water [4]. As a result of such snow volume melting, the river runoff volume increase occurs. Overflow of located within the city limits, emergency water discharge increases the water flow destructive power, overlapping the flood wave that leads to catastrophic consequences (catastrophic flooding in the city of Krymsk, 2012). Often flooding the city during snow melt flood periods is anthropogenic in nature and is associated with a network of reclamation channels for discharging rain and melt water from the city. Clearing of channels is not properly carried out, and in some cases, the channels are stopped or completely buried, which leads to support and flooding of the territory from where the discharge of water is not possible. Taking into account the high groundwater levels, when forming the supports on the irrigation and drainage canals, during spring snowmelt, they come out to the surface, increasing the levels of flooding.

Thus, as a result of economic water consumption and wastewater, household sewage is discharged into the urban sewage system and further into rivers. This increases the built-up 
areas flooding depth and affects the engineering and geological characteristics of soils within the city limits (flooding on the Amur River, 2013) [3]. The engineering protection security degree from hazardous processes in the region settlements is not sufficient. The engineering protection facilities construction was carried out on some settlements territories in the 60-70 years of XX century (Nevelsk, Kholmsk, Yuzhno-Sakhalinsk, Uglegorsk). These structures were represented by flood control dams and bank protection structures, but no integrated flood protection was built in any settlement [3]. To date, most of the buildings have become unusable and do not provide even minimal territory protection. The engineering protection, being built in some settlements, does not correspond to the danger of the territory. Design decisions are made by developers without agreement with the construction supervision authorities and without taking into account the hazardous processes characteristics.

\section{Decision}

The first action to reduce the risks from flooding in the settlements territory is the flood map development. Such maps preparation should be carried out at the stage of development and / or adjustment of master urban districts plans and territorial planning schemes. The use of small-scale maps of 1: 100,000 and 1: 500,000 does not allow us to zoning the territory according to the flooding degree with the necessary accuracy. Therefore, the Sakhalin region Construction Ministry, taking into account the Sakhalin Branch of the Far East Branch of the Far Eastern Branch of the Russian Academy of Sciences recommendations, decided to develop the "Planning Constraints Schemes" (hereinafter referred to as "the Schemes ...") to the Sakhalin region settlements general plans, which is one of the main steps to minimize the risks from hazardous natural processes, including floods.

"Planning restrictions schemes" (floods danger, the channel processes impact risk) to the Sakhalin region settlements general plans were developed on a scale of 1: 5000 - 1: 10000. Based on the received full-scale and calculated data, 8 flood hazard categories were identified in part territory flooding (Table 1). Flood hazard categories were determined on the basis of: the flooding area depth, the maximum flow velocity on the flooded area, the flood wave impact on buildings, structures, impacts on life support facilities, infrastructure and population.

Table 1. Category of flood hazard in the Sakhalin region.

\begin{tabular}{|c|c|c|c|c|c|}
\hline Category & $\begin{array}{l}\text { Depthofex } \\
\text { ceedance } \\
\text { probabilit } \\
\text { y, m }\end{array}$ & $\begin{array}{c}\text { Flow } \\
\text { velocity, } \\
\mathrm{m} / \mathrm{s}\end{array}$ & Impact on buildings & $\begin{array}{c}\text { Impacts on the } \\
\text { territory, life support } \\
\text { facilities, } \\
\text { infrastructure and } \\
\text { population } \\
\end{array}$ & $\begin{array}{l}\text { Protect the } \\
\text { population }\end{array}$ \\
\hline 1 & 2 & 3 & 4 & 5 & 6 \\
\hline $\mathbf{I}$ & $5,5-6,5$ & $4,5-5,0$ & $\begin{array}{l}\text { - Complete wooden } \\
\text { housesdestruction, low-rise } \\
\text { brick buildings and } \\
\text { medium-storey buildings ( } 4 \\
\text { floors or more), industrial } \\
\text { buildings with a light metal } \\
\text { frame and frameless } \\
\text { buildings } \\
\text { - Severe damage to } \\
\text { industrial buildings with a } \\
\text { heavy metal or reinforced } \\
\text { concrete frame (claydite- } \\
\text { concrete panel walls) }\end{array}$ & $\begin{array}{l}\text { - The territoryflooding } \\
\text { - Power outage. } \\
\text { - The water supply and } \\
\text { sewerage } \\
\text { systemsfailure } \\
\text { - Impossibility of } \\
\text { further residence in the } \\
\text { housing stock }\end{array}$ & $\begin{array}{l}\text { The territory } \\
\text { engineering } \\
\text { protection } \\
\text { construction. } \\
\text { Before the defense } \\
\text { construction - the } \\
\text { population evacuation }\end{array}$ \\
\hline II & $4,5-5,5$ & $3,5-4,5$ & $\begin{array}{l}\text { - Completewoodenhouses } \\
\text { destruction, low- } \\
\text { risebrickbuildings, }\end{array}$ & $\begin{array}{l}\text { - Flooding of the } \\
\text { territory } \\
\text { - Power outage. }\end{array}$ & $\begin{array}{l}\text { The territory } \\
\text { engineering }\end{array}$ \\
\hline
\end{tabular}




\begin{tabular}{|c|c|c|c|c|c|}
\hline & & & $\begin{array}{l}\text { industrial buildings with a } \\
\text { light metal frame and } \\
\text { frameless buildings } \\
\text { - Strong damage to } \\
\text { medium-storey brick houses } \\
\text { ( } 4 \text { floors or more) } \\
\text { - Easy damage to concrete } \\
\text { and reinforced concrete } \\
\text { buildings, seismic structures }\end{array}$ & $\begin{array}{l}\text { - The failure of water } \\
\text { supply and sewerage } \\
\text { systems } \\
\text { - Impossibility of } \\
\text { further residence in the } \\
\text { housing stock }\end{array}$ & $\begin{array}{l}\text { protection } \\
\text { construction. } \\
\text { Before the defense } \\
\text { construction - the } \\
\text { population evacuation }\end{array}$ \\
\hline III & $3,5-4,5$ & $2,5-3,5$ & $\begin{array}{l}\text { - Complete residential and } \\
\text { industrial premises flooding } \\
\text { - Complete wooden houses } \\
\text { and structuresdestruction } \\
\text { - Strong damage to low- } \\
\text { rise brick buildings (1-2 } \\
\text { floors), industrial buildings } \\
\text { with a light metal frame and } \\
\text { frameless buildings } \\
\text { - Easy damage to } \\
\text { industrial buildings with a } \\
\text { heavy metal or reinforced } \\
\text { concrete frame (claydite } \\
\text { concrete walls) }\end{array}$ & $\begin{array}{l}\text { - Flooding of the } \\
\text { territory } \\
\text { - Power outage. } \\
\text { - The failure of water } \\
\text { supply and sewerage } \\
\text { systems } \\
\text { - Impossibility of } \\
\text { further residence in the } \\
\text { housing stock }\end{array}$ & $\begin{array}{l}\text { The territory } \\
\text { engineering } \\
\text { protection } \\
\text { construction. } \\
\text { Before the defense } \\
\text { construction - the } \\
\text { population evacuation }\end{array}$ \\
\hline IV & $2,5-3,5$ & $2,0-2,5$ & $\begin{array}{l}\text { - Residential and industrial } \\
\text { premises flooding } \\
\text { - Easy damage to low-rise } \\
\text { brick buildings (1-2 } \\
\text { storeys), industrial buildings } \\
\text { with a light metal frame and } \\
\text { frameless buildings } \\
\text { - Severe wooden houses } \\
\text { and structures damage }\end{array}$ & $\begin{array}{l}\text { - The territory flooding } \\
\text { - Power outage. } \\
\text { - The water supply and } \\
\text { sewerage systems } \\
\text { failure } \\
\text { - Impossibility of } \\
\text { further residence in the } \\
\text { housing stock }\end{array}$ & $\begin{array}{l}\text { The territory } \\
\text { engineering } \\
\text { protection } \\
\text { construction. } \\
\text { Before the defense } \\
\text { construction - the } \\
\text { population evacuation }\end{array}$ \\
\hline $\mathbf{V}$ & $1,5-2,5$ & $1,5-2,0$ & $\begin{array}{l}\text { - Partial residential and } \\
\text { industrial premisesflooding } \\
\text { - Easy damage to low-rise } \\
\text { brick buildings, industrial } \\
\text { buildings with a light metal } \\
\text { frame and frameless } \\
\text { buildings } \\
\text { - Severe wooden houses } \\
\text { and structures damage }\end{array}$ & $\begin{array}{l}\text { - Flooding and erosion } \\
\text { of orchards, fields and } \\
\text { roads } \\
\text { - Power supply } \\
\text { limitation } \\
\text { - Violation of the } \\
\text { functioning of water } \\
\text { supply and sewerage } \\
\text { systems }\end{array}$ & $\begin{array}{l}\text { The territory } \\
\text { engineering } \\
\text { protection } \\
\text { construction. } \\
\text { Before the } \\
\text { engineering } \\
\text { protection } \\
\text { construction, partial } \\
\text { population evacuation } \\
\text { from the most } \\
\text { dangerous zones }\end{array}$ \\
\hline VI & $0,5-1,5$ & $1,0-1,5$ & $\begin{array}{l}\text { - Partial residential and } \\
\text { industrial premises flooding } \\
\text { - Wooden houses and } \\
\text { structures damage }\end{array}$ & $\begin{array}{l}\text { - Flooding and erosion } \\
\text { of orchards, fields and } \\
\text { roads } \\
\text { - Short-term power } \\
\text { supply restriction } \\
\text { - Water supply and } \\
\text { sewerage systems } \\
\text { function as usual } \\
\end{array}$ & $\begin{array}{l}\text { Engineering } \\
\text { structures } \\
\text { construction for } \\
\text { passing storm and } \\
\text { melt run off }\end{array}$ \\
\hline VII & $<0,5$ & $<1,0$ & $\begin{array}{l}\text { Farm buildings and ancillary } \\
\text { farms insignificant flooding }\end{array}$ & $\begin{array}{l}\text { - Insignificant flooding } \\
\text { of orchards, fields and } \\
\text { roads } \\
\text { - Stable power supply } \\
\text { - Water supply and } \\
\text { sewerage systems } \\
\text { function as usual }\end{array}$ & $\begin{array}{l}\text { Engineering } \\
\text { structures } \\
\text { construction for } \\
\text { passing storm and } \\
\text { melt run off }\end{array}$ \\
\hline
\end{tabular}

In terms of the channel processes danger, four channel process hazards categories were identified. The channel processes risk categories on the settlements territory were determined on the basis of: the maximum possible vertical channel deformations, planned channel 
deformations and the channel processes influence on the residential area, facilities and facilities located on the sites in question.

The obtained hazard categories make it possible to single out zones with different degrees of impact on the territory, buildings and structures during flooding on the settlements territory. An example of the planning restrictions to the general settlement plan scheme (flooding risk in Yuzhno-Sakhalinsk, security 1\%) is shown in Figure 1.

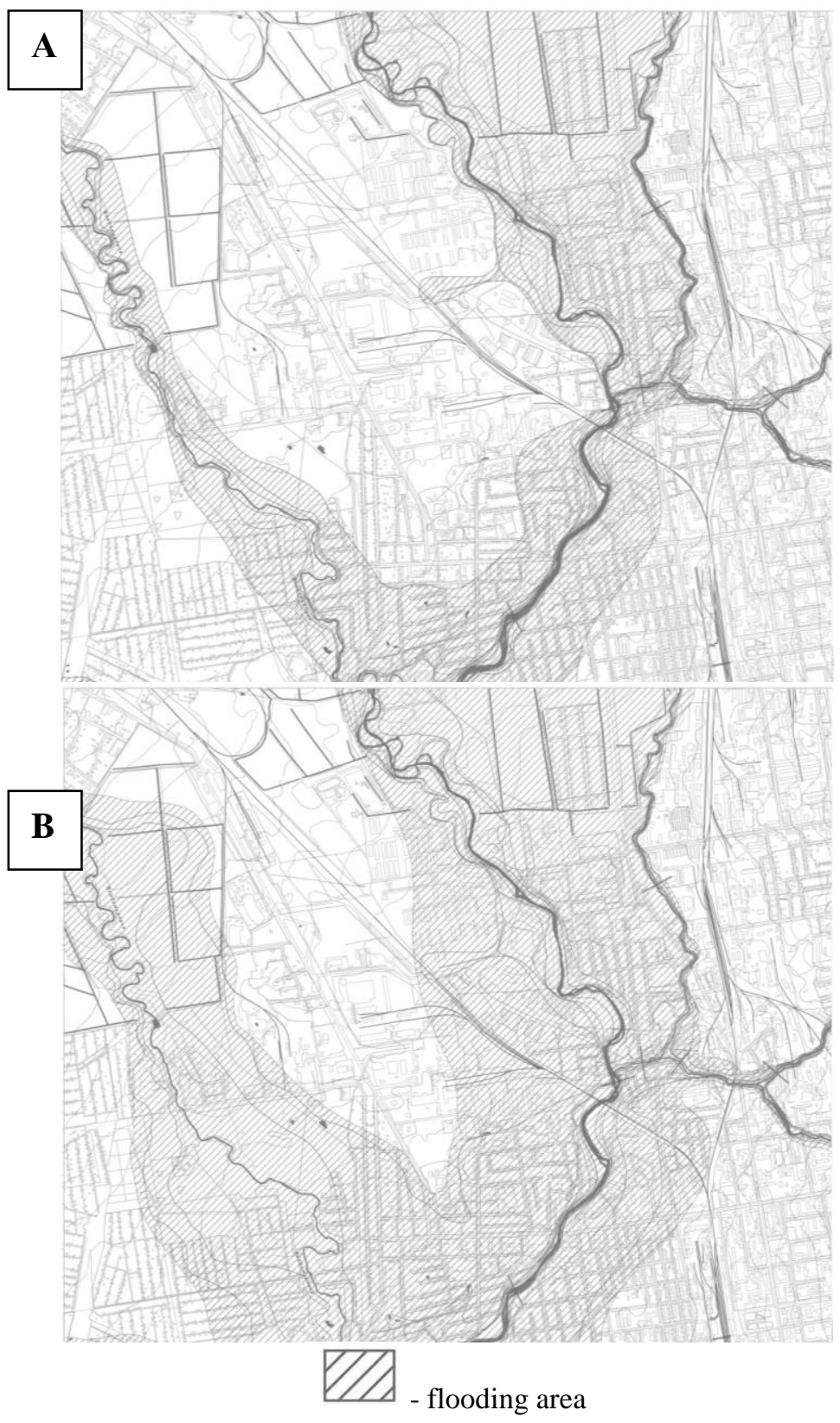

Fig. 1. Theplanning restrictions to the settlement general plan layout example (the flooding danger in Yuzhno-Sakhalinsk, occurrence of A - $1 \%$ and B - 0,1\%). 
Thus, local administrations, having "Schemes ..." precisely and specifically can perform zoning and all planning restrictions in the settlements territories.

\section{Conclusion}

"Schemes ..." to the Sakhalin region settlements general plans (floods danger and channel processes) in the scale of 1: 5000-1: 10000 allow to develop measures to protect the population and facilities from floods and channel processes, and also to reduce the possible damage from their impact, on the territory, facilities and structures.

The sections with different hazard categories allocated on the "Schemes ..." contribute to making decisions on the engineering protection structures construction priority, and in case of impossibility to build protection, the object move beyond the danger zone.

\section{References}

1. Yu.V. Gensiorovskiy, Exogenous geological processes and their influence on the territorial planning of cities (on the example of Sakhalin Island), (PhD Thesis, 2011)

2. N.A. Kazakov, Yu.V. Gensiorovskiy, The effect of the vertical sediment gradient on the characteristics of hydrological, avalanche and mudflow processes in the low mountains (2007)

3. Resources of surface waters of the USSR. Basin rivers of the Sakhalin and the Kuril Islands (1973)

4. A.A. Muzychenko, V.A. Lobkina, Reports of the second Baikal International Scientific and Practical Conf., Snow cover, atmospheric precipitation, aerosols: technology, climate and ecology, Unmanned aircraft use for anthropogenic snow patches research (2015) 